\title{
Histopathology of crustose coralline algae affected by white band and white patch diseases
}

Gaëlle Quéré, Anne-Leila Meistertzheim, Robert S. Steneck, Maggy M Nugues

Crustose coralline algae (CCA) are major benthic calcifiers that play crucial roles in marine ecosystems, particularly coral reefs. Over the past two decades, epizootics have been reported for several CCA species on coral reefs worldwide. However, their causes remain often unknown in part because few studies have investigated CCA pathologies at a microscopic scale. We studied the cellular changes associated with two syndromes: Coralline White Band Syndrome (CWBS) and Coralline White Patch Disease (CWPD) from samples collected in Curaçao, southern Caribbean. Healthy-looking tissue of diseased CCA did not differ from healthy tissue of healthy CCA. In diseased tissues of both pathologies, the three characteristic cell layers of CCA revealed cells completely depleted of protoplasmic content, but presenting an intact cell wall. In addition, CWBS showed a transition area between healthy and diseased tissues consisting of cells partially deprived of protoplasmic material, most likely corresponding to the white band characterizing the disease at the macroscopic level. This transition area was absent in CWPD. Regrowth at the lesion boundary were sometimes observed in both syndromes. Tissues of both healthy and diseased CCA were colonised by diverse boring organisms. Fungal infections associated with the diseased cells were not seen. However, other bioeroders were more abundant in diseased vs healthy CCA and in diseased vs healthy-looking tissues of diseased CCA. Although their role in the pathogenesis is unclear, this suggests that disease increases CCA susceptibility to bioerosion. Further investigations using an integrated approach are needed to carry out the complete diagnosis of these diseases. 
2 Histopathology of crustose coralline algae affected by white band and white patch diseases

3

4 Gaëlle Quéré1,2*, Anne-Leila Meistertzheim ${ }^{2}$, Robert S. Steneck ${ }^{3}$ and Maggy M. Nugues ${ }^{2,4}$

5

6 1) Leibniz Center for Tropical Marine Ecology (ZMT), Fahrenheitstr. 6, 28359 Bremen,

7 Germany

8 2) Laboratoire d'Excellence 'CORAIL' and USR 3278 CRIOBE EPHE-CNRS-UPVD, 58 Av.

9 Paul Alduy, 66860 Perpignan Cedex, France

10 3) Darling Marine Center, School of Marine Sciences, University of Maine, 193 Clark's Cove 11 Road, Walpole, ME 04573, USA

12 4) Carmabi Foundation, Piscaderabaai z/n, PO Box 2090, Willemstad, Curaçao

* Corresponding author: queregaelle@gmail.com

16 Running page head: Histopathology of CCA diseases

18 Key words: Disease, histopathology, crustose coralline algae, cell death, boring fauna,

19 regeneration, lesion 


\section{Abstract}

Crustose coralline algae (CCA) are major benthic calcifiers that play crucial roles in marine ecosystems, particularly coral reefs. Over the past two decades, epizootics have been reported for several CCA species on coral reefs worldwide. However, their causes remain often unknown in part because few studies have investigated CCA pathologies at a microscopic scale. We studied the cellular changes associated with two syndromes: Coralline White Band Syndrome (CWBS) and Coralline White Patch Disease (CWPD) from samples collected in Curaçao, southern Caribbean. Healthy-looking tissue of diseased CCA did not differ from healthy tissue of healthy CCA. In diseased tissues of both pathologies, the three characteristic cell layers of CCA revealed cells completely depleted of protoplasmic content, but presenting an intact cell wall. In addition, CWBS showed a transition area between healthy and diseased tissues consisting of cells partially deprived of protoplasmic material, most likely corresponding to the white band characterizing the disease at the macroscopic level. This transition area was absent in CWPD. Regrowth at the lesion boundary were sometimes observed in both syndromes. Tissues of both healthy and diseased CCA were colonised by diverse boring organisms. Fungal infections associated with the diseased cells were not seen. However, other bioeroders were more abundant in diseased vs healthy CCA and in diseased vs healthy-looking tissues of diseased CCA. Although their role in the pathogenesis is unclear, this suggests that disease increases CCA susceptibility to bioerosion.

39 Further investigations using an integrated approach are needed to carry out the complete diagnosis of these diseases. 


\section{PeerJ Reviewing Manuscript}

\section{Introduction}

Scientific awareness that marine diseases represent a major threat to coral reefs has led to the multiplication of disease investigations over the past three decades (Weil 2001, Harvell et al. 2007, Pollock et al. 2011, Burge et al. 2014). Field monitoring surveys have considerably increased our knowledge about macroscopic characteristics, abundance and distribution of coral reef diseases and the environmental factors influencing their dynamics (Gladfelter 1982, Kuta \& Richardson 1996, Hayes \& Goreau 1998, Nugues 2002, Willis, Page \& Dinsdale 2004, Aeby et al. 2008, Weil, Croquer \& Urreiztieta 2009, Haapkylä et al. 2010, Tribollet, Aeby \& Work 2011). However, little progress has been made in elucidating disease causation due to the lack of microscopic pathology (Work \& Meteyer 2014). Coupled with microbial culture and molecular essays, histopathology appears as a crucial tool to determine the association between a pathogen and a tissue lesion. It is therefore a vital step in any effective coral reef disease survey (Work \& Meteyer 2014). It provides insight into cell pathology and host response to help resolve the question of disease causation (Work et al. 2014). It can detect etiological microorganisms and propose or refute potential causative agents by their observation in situ. Furthermore, it provides a great amount of information on the cell and tissue damages associated with gross lesions (Peters et al. 1984, Ainsworth et al. 2007a, Burns \& Takabayashi 2011, Williams et al. 2011, Sudek et al. 2012). Sometimes, even in the absence of pathogens, changes in the host tissue histology hint at the type of infection and lead to a diagnostic (Gupta et al. 2009). It is therefore the only current diagnostic tool that allows the establishment of a link between the potential causative agent and the specific changes in cell and tissue (Work \& Meteyer 2014). For instance, histology has confirmed the association between a fungus and the blue-black band lesion in crustose coralline algae (CCA) affected by the Coralline Fungal disease (CFD) (Williams et al. 2014). However, an integrated approach (i.e combining microbiological, microsensor, molecular 
67 and physiological techniques) is necessary in order to incriminate infectious agents as disease

68 causation and thus complete the diagnostic picture (Richardson et al. 2001, Work \& Meteyer 69 2014).

70 Unfortunately, investigations at the cellular level are seriously lacking in diseases

affecting CCA despite the importance of these calcifying algae in marine ecosystems, especially coral reefs. Along with scleractinian corals, CCA are important primary producers (Adey \& Macintyre 1973, Chisholm 2003) and framework builders (Adey \& Vassar 1975) delivering significant functional services in coral reef ecosystems, including enhancing coral larval settlement (Morse et al. 1988, Heyward \& Negri 1999, Harrington et al. 2004, Ritson-Williams et al. 2010, 2014). CCA are not spared by the increasing intensity and severity of marine diseases (Littler \& Littler 1995, Hayes \& Goreau 1998) and field investigations on CCA diseases have multiplied in recent years (Aeby et al. 2008, Vargas-Ángel 2010, Tribollet, Aeby \& Work 2011, Miller et al. 2013, Quéré, Steneck \& Nugues 2015). At present, six disease categories have been reported (Vargas-Ángel 2010, Williams et al. 2014, Quéré, Steneck \& Nugues 2015), but only CFD and coralline lethal orange disease (CLOD) have known causations. Virtually nothing is known about the other CCA disease categories and they remain histologically uncharacterized. Further knowledge on these diseases and the response of their host could be gained from studies at tissue and cellular levels.

In Curaçao, CCA species are affected by the Coralline White Band Syndrome (CWBS) and the Coralline White Patch Disease (CWPD) (Quéré, Steneck \& Nugues 2015). Both pathologies have the potential to reduce the survivorship and settlement of coral planulae and thus may have important implications for the maintenance and recovery of coral reefs (Quéré \& Nugues 2015). They differ in gross symptoms, spatio-temporal variations and lesion spread, 
90

91

92

93

94

95

96

97

98

99

100

101

102

103

104

105

106

107

108

109

110

111

112

113

suggesting that they may have different causations (Quéré, Steneck \& Nugues 2015). CWBS

lesions are defined by a white-band that appears centrally or peripherally and advances slowly

but steadily on the healthy tissue, while CWPD manifests by the presence of distinct white patches on the healthy crust, suggesting sudden losses of tissue (Fig. 1a \& b). Both diseases result in tissue loss with subsequent colonization by endophytic algae often leading to the death of the diseased patch in the case of CWBS (Quéré, Steneck \& Nugues 2015). Visible symptoms may have a biotic or abiotic origin. On one hand, thermal stress has been shown to cause bleaching in both corals and CCA in the laboratory (Anthony et al. 2008) and algal necroses appear on CCA crust under elevated temperature in aquaria (Martin \& Gattuso 2009). On the other hand, bacterial pathogens can also cause bleaching disease in the marine red algae Delisea pulchra (Fernandes et al. 2011). Gross symptoms in the shape of rings are known to be caused by a bacterial infection in the case of CLOD (Littler \& Littler 1995) and by fungi in the case of CFD (Williams et al. 2014). The aim of this study was to describe CWBS and CWPD at the microscopic level in order to better understand these diseases and their effects on coralline algal tissues.

\section{Materials and Methods}

7

\section{Field collection}

Crustose coralline algae were sampled in May 2012 at two sites along the leeward coast of Curaçao, Southern Caribbean $\left(12^{\circ} \mathrm{N}, 69^{\circ} \mathrm{W}\right)$. Fragments $\left(\mathrm{ca} .10-20 \mathrm{~cm}^{2}\right)$ from four CCA species were collected using hammer and chisel on the reef terrace at 5-10 m depth at two reef sites: Hydrolithon boergesenii, Neogoniolithon mamillare and Paragoniolithon accretum at Water Factory $\left(12^{\circ} 06^{\prime} 32^{\prime \prime} \mathrm{N}, 68^{\circ} 57^{\prime} 14^{\prime \prime} \mathrm{W}\right)$ and Paragoniolithon solubile at Playa Kalki $\left(12^{\circ} 22^{\prime} 30^{\prime \prime} \mathrm{N}\right.$, 
$\left.11469^{\circ} 09^{\prime} 31^{\prime \prime} \mathrm{W}\right)$. Sampling was not targeted towards particular species, but we sought to have an

115 approximately equal number of healthy and diseased samples. A total of 23 fragments, including

1167 healthy fragments, 8 fragments affected by CWBS and 8 fragments affected by CWPD, were

117 sampled (Table 1). For each diseased fragment collected, we made sure to incorporate healthy-

118 looking tissue. Each replicate was selected from a distinct patch. Healthy and diseased fragments

119 of each disease were placed in separated collecting bags to avoid contamination and transported

120 in the dark to the laboratory.

121

122 Histology

123 Back in the laboratory, a sample (ca. 2-4 $\mathrm{cm}^{2}$ ) of each fragment was kept for taxonomic

124 identification. The pieces used for taxonomic determination were rinsed with freshwater and

125 dried for six hours in the oven at $60^{\circ} \mathrm{C}$ before being checked under a dissecting scope for

126 reproductive and morphological features (Steneck 1986). The rest was fixed in 4\% Formalin-

127 seawater solution and stored in the fridge until further use. Before decalcification, a small piece

128 (ca. $1 \mathrm{~cm}^{2}$ ) was cut from each fragment so that only the crust of the CCA and a thin (ca. $5 \mathrm{~mm}$ )

129 layer of limestone underneath remained. All superficial epibionts (i.e. mostly filamentous algae)

130 present on the surface of the coralline algae were removed. In the case of diseased fragments,

131 each piece was chipped so that it included the boundary between healthy and diseased tissues.

132 Each sample was then placed in an individual container with $5 \%$ L-ascorbic acid solution

133 to gently decalcify over a period up to one week. The solution within each container was

134 refreshed every two days. Once the skeleton and limestone were dissolved, the tissue samples

135 were placed in individual embedding cassettes and dehydrated at room temperature in ascending

136 grades of ethanol $(70 \%, 80 \%, 95 \%, 100 \%, 100 \%)$ for 40 minutes each, followed by an 
137 immersion in limonene (three baths of 40 minutes each). Samples that could not be processed

138 immediately were stored in $70 \%$ ethanol for a maximum of 5 days. This additional step did not

139 affect the results (G. Quéré, personal observation). CCA tissue was then placed in three

140 successive baths of paraffin (Paraplast ${ }^{\circledR}$ Plus ${ }^{\mathrm{TM}}$ ) each time 40 minutes before being embedded

141 into paraffin blocks. Samples were orientated so that transverse sectioning was possible. The

142 blocks were stored overnight at $4^{\circ} \mathrm{C}$ in the fridge to ease withdrawal from the cassette the

143 following day. The blocks were sectioned (section thickness 5 and $7 \mu \mathrm{m}$ ) using low profile

144 microtome blades (Leica DB80 LX) mounted on a calibrated rotary microtome (LEICA ${ }^{\text {TM }}$

145 RM2245; Leica Mikrosystems GmbH, Wetzlar, Germany). Sections were floated onto water

$146\left(20^{\circ} \mathrm{C}\right)$, mounted onto clean slides and dehydrated on a slide drying bench for minimum 40

147 minutes at $50^{\circ} \mathrm{C}$.

148 Sections were then rehydrated and stained following the Sharman staining series

149 (Sharman 1943) modified from Ruzin (1999). This method stains the cell walls of plant tissue in

150 tannic acid and iron alum after the protoplasts have been stained in safranin and orange $\mathrm{G}$ (see

151 Document S2 for detailed staining procedure). Several other staining methods were tried, but this

152 method was the most effective to visualize the different cellular components of CCA. Sections

153 were then dehydrated in successive baths of ethanol (45\%,90\% and $100 \%)$ and cleared with

154 limonene. Coverslips were finally mounted using adhesive resin. We examined and

155 photographed 10 permanent histology sections of each CCA fragment using light microscopy

156 (Leica DM750) with integrated camera (Leica ICC50 HD) using the Leica LAS EZ software. 157

158 Analyses 
159 Host response was described at the microscopic level and interpreted by comparing normal

160 healthy fragments paired with diseased ones. The presence of invading organisms, their type and

161 localization within the tissue were recorded. In each fragment, organisms could be present in the

162 CCA crust (i.e epithallus, perithallus and/or hypothallus) or in the limestone underneath the

163 crust. In addition, in diseased fragments, we noted whether they were located in the healthy-

164 looking and/or diseased tissues of the fragments. The identification of the invading organisms

165 was beyond the scope of this study and was restricted to two boring categories: macroborers (i.e

166 boring sponges, helminths and others) and microborers (i.e cyanobacteria). Sample sizes were

167 not sufficient to allow robust statistical analysis. All results are reported for pooled species of

$168 \mathrm{CCA}$ as the number of replicates per species was too low to make comparisons between species,

169 but species-specific data are listed in Table S1.

\section{Results}

172 The four CCA species presented similar responses towards diseases. For both diseases, we observed no difference in cell structure and organization between healthy tissue of healthy CCA

174 and healthy-looking tissue of diseased CCA. Cell walls and contents in healthy-looking tissue of diseased CCA were intact without any apparent damage (Figs. 2b \& 3b). In contrast, the diseased part of the tissue showed distinct histological changes between diseases. Cells affected by both CWBS and CWPD presented no apparent damage of their cell walls, but showed a complete depletion of their protoplasmic content (Figs. 2d \& 3d). However, in all cases of CWBS, we observed a transition area between healthy and dead cells consisting of cells that were partially deprived of protoplasmic content (Fig. 2c). Cells containing what appeared to be a condensed nucleus or balled up cytoplasmic materials were also frequently observed (Fig. 4a insert). This 
182 transition area most likely corresponds to the white band in the gross morphology (Fig. 1a). It did

183 not exist in CWPD tissue where healthy-looking cells were in immediate vicinity of empty dead

184 cells (Fig. 3c). In two cases of CWBS and one case of CWPD, we observed an overgrowth of the

185 diseased/dead surface by the healthy crust, suggesting tissue recovery (Fig. 4a \& b).

186 Various macroborers and microborers were observed in both healthy and diseased tissues

187 (Fig. 5). They were more abundant in diseased fragments, particularly in CWBS. Of the 7

188 healthy fragments examined, 4 (57\%) had invading macro- and microorganisms versus all of 8

189 CWBS fragments and 5 (63\%) of the 8 CWPD fragments (Table 2). Of 13 diseased fragments

190 with evidence of boring organisms, sponges were most common (62\%) followed by other

191 macroborers (38\%) and cyanobacteria (31\%). Of the four healthy fragments with borers, 3 had

192 sponges and two had other macroborers and cyanobacteria were not encountered. Within

193 diseased fragments, borers were also more abundant in the diseased tissue of the fragments. Of

19413 diseased fragments, 5 (38\%) presented borers in their healthy-looking tissue, whereas 12 (92

$195 \%$ ) showed intrusion by borers in their diseased tissue (Table S1). However, boring organisms

196 were rarely present within or in the immediate vicinity of diseased cells. Boring organisms were

197 more abundant in the underlying limestone than in the CCA crust. In CWPD, borers were found

198 exclusively in the limestone of all 5 diseased fragments containing borers. Cyanobacteria were

199 never seen in the CCA crust. We did not visualize any fungal infections associated with the 200 diseased cells.

\section{Discussion}

203 This is the first study providing histological information on CWBS and CWPD. We found no

204 visible difference between healthy tissues of healthy and diseased crusts, which suggests that the 
action of the disease is localized, at least at the cellular scale. However, variations could occur at a smaller scale. For example, distinct differences in bacterial community between non-diseased corals and healthy-looking tissues of colonies affected by white band disease have been highlighted in Orbicella annularis using molecular techniques (Pantos et al. 2003). In tissue affected by both diseases, the three distinct cell layers characteristic of CCA (epithallus, perithallus and hypothallus) showed cells with an intact cell wall, but depleted from all cytoplasmic content as highlighted by a sudden change in the intensity of the staining. A plausible explanation to cell bleaching is the loss of pigments as already known in corals during bleaching events (Kleppel, Dodge \& Reese 1989). CCA contain phycobilins (phycoerythrin and phycocyanin) pigments that are present in living tissue. Their loss could be followed by tissue necrosis and death (Fernandes et al. 2011). CCA also commonly experience sloughing events (Keats et al. 1997). However, the signs detected in this study differ from sloughing. During a sloughing event, epithallial cells are lost or appear loose (Keats et al. 1997, Garbary et al. 2013). Here, they remained present in all the diseased fragments as clearly visible in Fig. 3.

Additionally, all the different cell layers showed similar changes in the diseased part of the crust (difference in cell staining intensity) whereas in the case of a sloughing event, only the superficial epithallial cells would have shown deterioration. In CWPD, healthy cells were in immediate vicinity of diseased empty cells whereas in CWBS, a transition area existed where cells had less protoplasmic content than healthy cells as highlighted by a weaker stain within the cells. This transition area could be the sign of a chronic, slowly progressing disease which is reflected in the slow but steady rates of CWBS progression on healthy tissue (i.e. $0.21 \pm 0.06 \mathrm{~cm} \mathrm{month}^{-1}$ in Quéré, Steneck \& Nugues 2015). In contrast, CWPD generally manifests by a sudden and extensive loss of tissue, often with a rapid turn-over 
228 (G. Quéré and M. Nugues, personal observations), characteristic of acute diseases (Work,

229 Russell \& Aeby 2012; McCoy and Kamenos 2015).

230 Dead cells were characterized by an intact cell wall and a complete loss of protoplasmic

231 content. In the case of CWBS, some cells in the transition area showed a highly visible nuclei or

232 rounded cytoplasmic content. Histology confirmed cell death but the technique used here did not

233 allow us to determine whether death was the result of necrosis or programmed cell death (PCD).

234 The former is triggered by external factors often affecting many cells within a tissue, while the

235 latter is triggered by intracellular signals activating specific gene expression at the level of a

236 single cell (Greenberg 1997, Dunn et al. 2012). These phenomena have rarely been studied in

237 multicellular algae (Garbary et al. 2013) and remain poorly understood. Both have been

238 highlighted during bleaching in the sea anemone Aiptasia sp. using a combination of histology,

239 electron microscopy and in-situ end labelling of DNA fragmentation (Dunn et al. 2002). In the

240 transition area, the sudden high visibility of the nuclei or rounded cytoplasmic content could be

241 related to the condensation of the nucleus during PCD. Similar cellular degradation has been

242 observed in Acroporid corals affected by white syndromes (Ainsworth et al. 2007b). However,

243 several other distinct features are necessary to differentiate necrosis (e.g vacuolization, cell

244 rupture, tissue degradation) and PCD (e.g cell shrinkage, formation of accumulation bodies)

245 (Dunn et al. 2002, Franklin, Brussaard \& Berges 2006). Interestingly, plants can also present a

246 hypersensitive response that consists of rapid death after infection by a pathogen (e.g fungi,

247 bacteria, viruses, nematodes) in order to prevent its spread (Garbary et al. 2013). This

248 phenomenon could constitute a plausible explanation for the CWPD symptoms. However,

249 further analyses are required to test this hypothesis. 
We observed regrowth of healthy-looking tissue over diseased tissue in both diseases. In

251

252

253

254

255

256

257

258

259

260

261

262

263

264

265

266

267

268

269

270

271

272

reef-building corals, an immune response and repair mechanism consisting of a locally

accelerated growth has been shown in wounded colonies (D'Angelo et al. 2012). We could

interpret this regrowth as a response of the remaining healthy tissue to counteract the progression

of the lesion like a wound healing response in CCA. Similarly, CCA are capable of healing wounds caused by herbivores grazing on their crust by regeneration of perithallial cells within the thallus (Steneck 1983). This healing response could explain the presence of CCA cells lining up the burrow around the invading organisms (Fig. 5b).CCA may have repaired cells around those damaged by the borer. Alternatively, the algal tissue could have grown around the invaders.

We found various metazoa (sponges, helminth, bivalve juveniles) and microrganisms (cyanobacteria) associated with both healthy and diseased CCA tissue. This is consistent with previous studies which have shown the presence of those organisms in healthy and diseased coral colonies (Work \& Aeby 2011, Séré et al. 2013) and in live and dead coralline thalli (Tribollet \& Payri 2001). These organisms were more abundant in diseased than healthy CCA fragments, and, within diseased fragments, they were more abundant in diseased vs healthy tissue, suggesting a potential link between CCA diseases and the presence of borers. However, it is unknown whether these borers are the cause of the disease or opportunistic secondary colonizers. Among the organisms observed here, several have been identified as pathogenic in other species. This is the case for helminths known to cause tissue loss in Montipora (Jokiel \& Townsley 1974) or cyanobacteria which appear to cause tissue lysis and necrosis in black band diseased corals (Ainsworth et al. 2007a). Ciliates are also frequently associated with diseases and capable of invading animal and plant tissue by breaking cell membranes and walls using enzymes such as 
273 proteases (Work \& Aeby 2011). In our observations, boring organisms did not seem to be

274 associated with evident cell pathology, suggesting a secondary invasion. Indeed, diseases may

275 weaken or damage coralline tissues, thus facilitating invasion by borers. The mechanical (chip

276 production) and chemical (dissolution) bioerosion of calcium carbonate by boring sponges or

277 bivalves has been reported (Lazar \& Loya 1991, Zundelevich, Lazar \& Ilan 2007). In our study,

278 the acellular space observed around the different invaders could be due to a digestive effect of

279 the borer on the surrounding CCA cells creating a dead zone around them. It is also possible that

280 the presence of an organism would have weakened the tissue around it leading to its loss during

281 fixation.

282

283

causing higher rates of erosion in dead versus live thalli (Tribollet \& Payri 2001). The same way

284

dead coral skeletons are colonised at the surface and bored inwards, diseased crusts could

285

become rapidly vulnerable to invaders (Tribollet \& Payri 2001). Previous studies looking at the

286

association between host response and potential agents revealed that sponges, cyanobacteria and

287

helminths are absent from acute lesions but often associated with chronic diseases, such as the

288

slowly progressing phases of White Syndromes in Montipora capitata (Work et al. 2012). Our

289

observations confirm this pattern since sponges were often found spreading through the crust and

290

the limestone in CWBS fragments. In contrast, in CWPD fragments, sponges were exclusively

291

located in the limestone, suggesting that they did not have time to invade the crust. There is

292

evidence that macroborers such as bivalves or sponges could take a couple of years to colonize

293

dead skeleton, as they are long-lived, slow-growing organisms (Tribollet \& Golubic 2011).

The increase of borers within the coralline tissue could have a cascading effect by making

295 carbonate substrata available to new borers, thus increasing their eroding action. Ocean 
296

297

298

299

300

301

302

303

acidification also accelerates reef bioerosion without necessarily affecting the health of boring organisms (Wisshak et al. 2013). Furthermore, synergistic effects of ocean warming, ocean acidification and disease infection enhance the reduction in the calcification rates of CCA (Williams et al. 2014). In the face of climate change, disease outbreaks may thus, together with global stressors and boring organisms, aggravate reef degradation.

Histological observations of lesions from the two diseases did not reveal any evidence for the presence of fungi. A fungus belonging to the subphylum Ustilaginomycetes has been identified as the pathogenic agent responsible for CFD thanks to conventional histology (Williams et al. 2014). We could deduce that fungi are not implicated in CWBS and CWPD. Similarly, fungi were not observed in the white syndrome of Acroporid corals (Ainsworth et al. 2007b). Our method did not allow for the visualization of bacteria which have been identified as causal agents for CLOD (Littler \& Littler 1995). Visualizing bacteria using conventional histology would have required the use of Taylor's gram stains (Peters et al. 1983, Work \& Rameyer 2005). Additional techniques such as the embedding of tissue in agar and the use of fluorescence in situ hybridisation (FISH) or transmission electron microscopy (TEM) (Work, Russell \& Aeby 2012) have also been suggested to improve bacterial detectability in coral tissues (Bythell et al. 2002). The same applies for virus-like particules (VLPs) whose presence can be detected using TEM and flow cytometry (Davy et al. 2006). Viruses have been associated with the presence of syncitia inside cells (Work, Russell \& Aeby 2012); however, they were not observed in this study. The potential implication of viruses in coral disease is still unknown but thermally stressed corals produce numerous VLPs (Davy et al. 2006, Rosenberg et al. 2009). Although this study did not identify the agents responsible of the diseases, it allows to narrow the pool of 
318 potential suspects. The use of an integrated approach is necessary for further progress on the

319 complete diagnosis of CCA disease.

320

321 Conclusions

322 This study brings a descriptive distinction at the cellular level between CWBS and CWPD.

323 Observations of the diseased tissues were consistent with the signs described in the field. CWBS

324 known to progress slowly but steadily over the CCA in the field showed a transition zone in

325 microscopy. In contrast, CWPD known to cause a sudden loss of tissue in CCA had no transition

326 zone. Although boring organisms were observed at higher abundances within diseased tissues in

327 comparison to healthy ones, we did not find evidence of a direct link between the presence of

328 invaders and the disease lesion. However, the range of potential pathogens could be narrowed as

329 no sign of fungal infection was observed. Standard techniques in histopathology alone cannot

330 elucidate the question of disease causation. Additional methods are necessary to complete the

331 diagnosis picture.

332

\section{Acknowledgements}

334 We wish to thank the Carmabi foundation and staff for logistic support. Aline Tribollet,

335 Elisabeth Faliex, and Thierry Work kindly assisted with identification of invading organisms and 336 interpretation of the micrographs. We also thank Anna Le Ruz for assistance in the laboratory. 


\section{References}

Adey WH, Macintyre IG. 1973. Crustose Coralline Algae: A Re-evaluation in the Geological Sciences. Geol Soc Am Bull 84:883-904

Adey WH, Vassar JM. 1975. Colonization, succession and growth rates of tropical crustose coralline algae (Rhodophyta, Cryptonemiales). Phycologia 14:55-69

Aeby GS, Work T, Fenner D, Didonato E. 2008. Coral and crustose coralline algae disease on the reefs of American Samoa. Proc 11th Int Coral Reef Symp 1:200-204

Ainsworth TD, Kramasky-Winter E, Loya Y, Hoegh-Guldberg O, Fine M. 2007a. Coral Disease Diagnostics: What's between a Plague and a Band? Appl Environ Microbiol 73:981-992

Ainsworth TD, Kvennefors EC, Blackall LL, Fine M, Hoegh-Guldberg O. 2007b. Disease and cell death in white syndrome of Acroporid corals on the Great Barrier Reef. Mar Biol 151:19-29

Anthony KRN, Kline DI, Diaz-Pulido G, Dove S, Hoegh-Guldberg O. 2008. Ocean acidification causes bleaching and productivity loss in coral reef builders. Proc Natl Acad Sci 105:17442-17446

Berges JA, Falkowski PG. 1998. Physiological stress and cell death in marine phytoplankton: Induction of proteases in response to nitrogen or light limitation. Limnol Oceanogr 43:129-135

Burge CA, Mark Eakin C, Friedman CS, Froelich B, Hershberger PK, Hofmann EE, Petes LE, Prager KC, Weil E, Willis BL, Ford SE, Harvell CD (2014) Climate Change Influences on Marine Infectious Diseases: Implications for Management and Society. Annu Rev Mar Sci 6:249-277

Burns J, Takabayashi M. 2011. Histopathology of Growth Anomaly Affecting the Coral, Montipora capitata: Implications on Biological Functions and Population Viability. PLoS ONE 6:e28854

Chisholm JRM. 2003. Primary productivity of reef-building crustose coralline algae. Limnol Oceanogr 48:1376-1387

D’Angelo C, Smith EG, Oswald F, Burt J, Tchernov D, Wiedenmann J. 2012. Locally accelerated growth is part of the innate immune response and repair mechanisms in reefbuilding corals as detected by green fluorescent protein (GFP)-like pigments. Coral Reefs 31:1045-1056

Davy S, Burchett S, Dale A, Davies P, Davy J, Muncke C, Hoegh-Guldberg O, Wilson W. 2006. Viruses: agents of coral disease? Dis Aquat Organ 69:101-110 
Dunn SR, Bythell JC, Le Tissier MD., Burnett WJ, Thomason JC 2002. Programmed cell death and cell necrosis activity during hyperthermic stress-induced bleaching of the symbiotic sea anemone Aiptasia sp. J Exp Mar Biol Ecol 272:29-53

Dunn SR, Pernice M, Green K, Hoegh-Guldberg O, Dove SG. 2012. Thermal Stress Promotes Host Mitochondrial Degradation in Symbiotic Cnidarians: Are the Batteries of the Reef Going to Run Out? Plos One 7:e39024

Fernandes N, Case RJ, Longford SR, Seyedsayamdost MR, Steinberg PD, Kjelleberg S, Thomas T. 2011. Genomes and Virulence Factors of Novel Bacterial Pathogens Causing Bleaching Disease in the Marine Red Alga Delisea pulchra. Plos One 6:e27387

Franklin DJ, Brussaard CPD, Berges JA. 2006. What is the role and nature of programmed cell death in phytoplankton ecology? European Journal of Phycology 41:1-14

Garbary DJ, Galway ME, Lord CE and Gunawardena AN. 2013. Programmed cell death in multicellular algae. In: Kirsten Heimann and Christos Katsaros, ed. Walter de Gruyter GmbH, Berlin, 1-19

Gladfelter WB. 1982. White-band Disease in Acropora Palmata: Implications for the Structure and Growth of Shallow Reefs. Bull Mar Sci 32:639-643

Greenberg JT. 1997. Programmed cell death in plant-pathogen interactions. Annu Rev Plant Physiol Plant Mol Biol 48:525-545

Gupta E, Balla P, Khurana N, Singh T. 2009. Histopathology for the diagnosis of infectious diseases. Indian J Med Microbiol 27:100-106

Haapkylä J, Melbourne-Thomas J, Flavell M, Willis BL. 2010. Spatiotemporal patterns of coral disease prevalence on Heron Island, Great Barrier Reef, Australia. Coral Reefs 29:10351045

Harrington L, Fabricius K, De'Ath G, Negri A. 2004. Recognition and selection of settlement substrata determine post-settlement survival in corals. Ecology 85:3428-3437

Harvell D, Jordán-Dahlgren E, Merkel S, Rosenberg E, Raymundo L, Smith G, Weil E, Willis B. 2007. Coral disease, environmental drivers, and the balance between coral and microbial associates. Oceanography 20:172-195

Hayes RL, Goreau NI. 1998. The significance of emerging diseases in the tropical coral reef ecosystem. Rev Biol Trop 46:173-185

Heyward AJ, Negri AP. 1999. Natural inducers for coral larval metamorphosis. Coral Reefs 18:273-279

Jokiel PL, Townsley SJ. 1974. Biology of the Polyclad Prosthiostomum (Prosthiostomum) sp., a New Coral Parasite from Hawaii. Pacific Science 28:361-373 
404

405

406

407

408

409

410

411

412

413

414

415

416

417

418

419

420

421

422

423

424

425

426

427

428

429

430

431

432

433

434

435

436

Keats DW, Knight MA, Pueschel CM. 1997. Antifouling effects of epithallial shedding in three crustose coralline algae (Rhodophyta, Coralinales) on a coral reef. J Exp Mar Biol Ecol 213:281-293

Kuta KG, Richardson LL. 1996. Abundance and distribution of black band disease on coral reefs in the northern Florida keys. Coral Reefs 15:219-223

Kleppel GS, Dodge RE, Reese CJ. 1989. Changes in pigmentation associated with the bleaching of stony corals. Limnol Oceanogr 34:1331-1335

Lazar B, Loya Y. 1991. Bioerosion of coral reefs-A chemical approach. Limnol Oceanogr $36: 377-383$

Littler MM, Littler DS. 1995. Impact of CLOD pathogen on Pacific coral reefs. Science 267:1356-1360

Martin S, Gattuso J-P. 2009. Response of Mediterranean coralline algae to ocean acidification and elevated temperature. Glob Change Biol 15:2089-2100

McCoy SJ, Kamenos NA. 2015. Coralline algae (Rhodophyta) in a changing world: integrating ecological, physiological, and geochemical responses to global change. J Phycol 51:6-24

Miller IR, Logan M, Johns KA, Jonker MJ, Osborne K, Sweatman HPA. 2013. Determining background levels and defining outbreaks of crustose coralline algae disease on the Great Barrier Reef. Mar Freshw Res 64:1022-1028

Morse DE, Hooker N, Morse ANC, Jensen RA. 1988. Control of larval metamorphosis and recruitment in sympatric agariciid corals. J Exp Mar Biol Ecol 116:193-217

Nugues MM. 2002. Impact of a coral disease outbreak on coral communities in St. Lucia: what and how much has been lost? Mar. Ecol. Prog. Ser 229: 61-71

Pantos O, Cooney RP, Le Tissier MDA, Barer MR, O’Donnell AG, Bythell JC. 2003. The bacterial ecology of a plague-like disease affecting the Caribbean coral Montastrea annularis. Environ Microbiol 5:370-382

Peters EC. 1983. Possible agent of "White Band Disease" in Caribbean Acroporid corals. Journal of Invertebrate Pathology 41: 394-396

Peters EC. 1984. A survey of cellular reactions to environmental stress and disease in Caribbean scleractinian corals. Helgoländer Meeresunters. 37:113-137

Pollock FJ, Morris PJ, Willis BL, Bourne DG. 2011. The Urgent Need for Robust Coral Disease Diagnostics. PLoS Pathog 7:e1002183

Quéré G, Steneck RS, Nugues MM. 2015. Spatiotemporal and species-specific patterns of diseases affecting crustose coralline algae in Curaçao. Coral Reefs 34: 259-273 
Quéré G, Nugues MM. 2015. Coralline algae disease reduces survival and settlement success of coral planulae in laboratory experiments. Coral Reefs [doi: 10.1007/s00338-015-1292-0]

Richardson LL, Smith GW, Ritchie KB, Carlton RG. 2001. Integrating microbiological, microsensor, molecular, and physiologic techniques in the study of coral disease pathogenesis. Hydrobiologia 460:71-89

Ritson-Williams R, Arnold SN, Paul VJ, Steneck RS. 2014. Larval settlement preferences of Acropora palmata and Montastraea faveolata in response to diverse red algae. Coral Reefs 33:59-66

Ritson-Williams R, Paul V, Arnold S, Steneck R. 2010. Larval settlement preferences and postsettlement survival of the threatened Caribbean corals Acropora palmata and $A$. cervicornis. Coral Reefs 29:71-81

Rosenberg E, Kushmaro A, Kramarsky-Winter E, Banin E, Yossi L. 2009. The role of microorganisms in coral bleaching. Isme J 3:139-146

Ruzin SE. 1999. Plant Microtechnique and Microscopy. Oxford: Oxford University Press.

Séré MG, Tortosa P, Chabanet P, Turquet J, Quod J-P, Schleyer MH. 2013. Bacterial Communities Associated with Porites White Patch Syndrome (PWPS) on Three Western Indian Ocean (WIO) Coral Reefs. PLoS ONE 8:e83746

Sharman BC. 1943. Tannic Acid and Iron Alum with Safranin and Orange G in Studies of the Shoot Apex Biotech Histochem 18:105-111

Steneck RS. 1983. Escalating Herbivory and Resulting Adaptive Trends in Calcareous Algal Crusts. Paleobiology 9:44-61

Steneck RS. 1986. The Ecology of Coralline Algal Crusts: Convergent Patterns and Adaptative Strategies. Annu Rev Ecol Syst 17:273-303

Sudek M, Work TM, Aeby GS, Davy SK. 2012. Histological observations in the Hawaiian reef coral, Porites compressa, affected by Porites bleaching with tissue loss. J Invertebr Pathol 111:121-125

Tribollet A, Payri C. 2001. Bioerosion of the coralline alga Hydrolithon onkodes by microborers in the coral reefs of Moorea, French Polynesia. Oceanol Acta 24:329-342

Tribollet A, Golubic S. 2011. Reef Bioerosion: Agents and Processes. In: Dubinsky Z., Stambler N. ed. Coral Reefs: An Ecosystem in Transition. Springer Netherlands, Dordrecht, 435449

Tribollet A, Aeby G, Work T. 2011. Survey and determination of coral and coralline algae diseases/lesions in the lagoon of New Caledonia. Scientific Report. COMPONENT 3D Project 3D3 Studies of coral diseases in New Caledonia. CRISP. New Caledonia 
471

472

473

474

475

476

477

478

479

480

481

482

483

484

485

486

487

488

489

490

491

492

493

494

495

496

497

498

499

500

Vargas-Ángel B. 2010. Crustose coralline algal diseases in the U.S.-Affiliated Pacific Islands. Coral Reefs 29:943-956

Weil E. 2001. Caribbean Coral reef Diseases, Status, and Research Needs. Workshop priorities for Caribbean Coral Reef Researchm Miami Priorities for Caribbean Coral Reef Research. A Workshop held October 3-5, 2001. RSMAS, U. of Miami, FL:

Weil E, Croquer A, Urreiztieta I. 2009. Temporal variability and impact of coral diseases and bleaching in La Parguera, Puerto Rico from 2003-2007. Caribb J Sci 45:221-246

Williams GJ, Knapp IS, Maragos JE, Davy SK. 2011. Response to Gardner et al. Mar Pollut Bull 62:2878-2879

Williams GJ, Price NN, Ushijima B, Aeby GS, Callahan S, Davy SK, Gove JM, Johnson MD, Knapp IS, Shore-Maggio A, Smith JE, Videau P, Work TM. 2014. Ocean warming and acidification have complex interactive effects on the dynamics of a marine fungal disease. Proc R Soc B Biol Sci 281:20133069

Willis BL, Page CA, Dinsdale EA. 2004. Coral disease on the Great Barrier Reef. In: Rosenberg E., Loya Y, ed. Coral Health and Disease. Springer, Berlin, Germany, 69-104

Wisshak M, Schönberg C, Form A, Freiwald A. 2013. Effects of ocean acidification and global warming on reef bioerosion-lessons from a clionaid sponge. Aquat Biol 19:111-127

Work TM, Rameyer RA. 2005. Characterizing lesions in corals from American Samoa. Coral Reefs 24:384-390

Work TM, Aeby GS. 2011. Pathology of tissue loss (white syndrome) in Acropora sp. corals from the Central Pacific. J Invertebr Pathol 107:127-131

Work TM, Russell R, Aeby GS. 2012. Tissue loss (white syndrome) in the coral Montipora capitata is a dynamic disease with multiple host responses and potential causes. Proc $R$ Soc B Biol Sci 279:4334-4341

Work TM, Aeby GS, Lasne G, Tribollet A. 2014. Gross and microscopic pathology of hard and soft corals in New Caledonia. J Invertebr Pathol 120:50-58

Work T, Meteyer C. 2014. To Understand Coral Disease, Look at Coral Cells. EcoHealth doi:10.1007/s10393-014-0931-1:1-9

Zundelevich A, Lazar B, Ilan M. 2007. Chemical versus mechanical bioerosion of coral reefs by boring sponges - lessons from Pione cf. vastifica. J Exp Biol 210:91-96 
501

502

503

504

505

506

507

508

509

510

511

512 Fig. 3 Transversal histological sections of the CCA, Hydrolithon boergesenii affected by CWPD

\section{Figure legends}

Fig. 1 Gross lesions of CCA diseases. (a) CWBS in the CCA, Paragoniolithon solubile and (b) CWPD in the CCA, Hydrolithon boergenesii from Curaçao in 2012. Black arrows show the white band in CWBS.

Fig. 2 Transversal histological sections of the CCA, Paragoniolithon solubile affected by CWBS stained in Sharman's (1943) stain. (a) overview with locations of the healthy, transition and dead areas enlarged in (b), (c) and (d). Note the progressive loss of staining from healthy tissue (HT) to dead tissue(DT). B, Boundary. Ep, epithallial cells. Cw, cell wall (silver stain). P, protoplasm (orange to dark stain).

513 stained in Sharman's (1943) stain. (a) overview with locations of the healthy (HT) and diseased 514 areas (DT) enlarged in (b) and (d). (c) shows the boundary (B) between healthy and diseased areas. Note the absence of a transition area highlighted by sudden loss of staining. B, Boundary.

516 Co, conceptacle. Ep, epithallial cells. Cw, cell wall (silver stain). P, protoplasm (orange to dark 517 stain).

518

519 Fig. 4 Regrowth of living crust. Regrowth of living crust in (a) CWBS and (b) CWPD. Remnant 520 healthy crust (red arrows) regrew upward and laterally over dead/dying crust. Insert in (a) 521 displays enlargement of the boundary area (B) with cells showing a condensed nucleus or 522 protoplasmic content (black arrows). Ep, epithallial cells. 
524 Fig. 5 Photomicrographs of the most commonly encountered organisms in healthy and diseased

525 CCA. (a) boring sponge characterized by silicaceous spicules (red arrow) (b) unidentified

526 macroborer. Note the CCA cells lining up the burrow suggesting the growth of the algae around

527 the invader (red arrow) and the acellular space around the organism (black arrow). (c)

528 unidentified macroborer, possibly a juvenile bivalve. (d) cyanobacterial trichomes (red arrows).

529 (e) helminth. $\mathrm{Cu}$, cuticule. L, lumen. 


\section{1}

Gross lesions of CCA diseases.

(a) CWBS in Paragoniolithon solubile and (b) CWPD in Hydrolithon boergesenii from Curaçao in 2012. Black arrow shows the white band in CWBS.
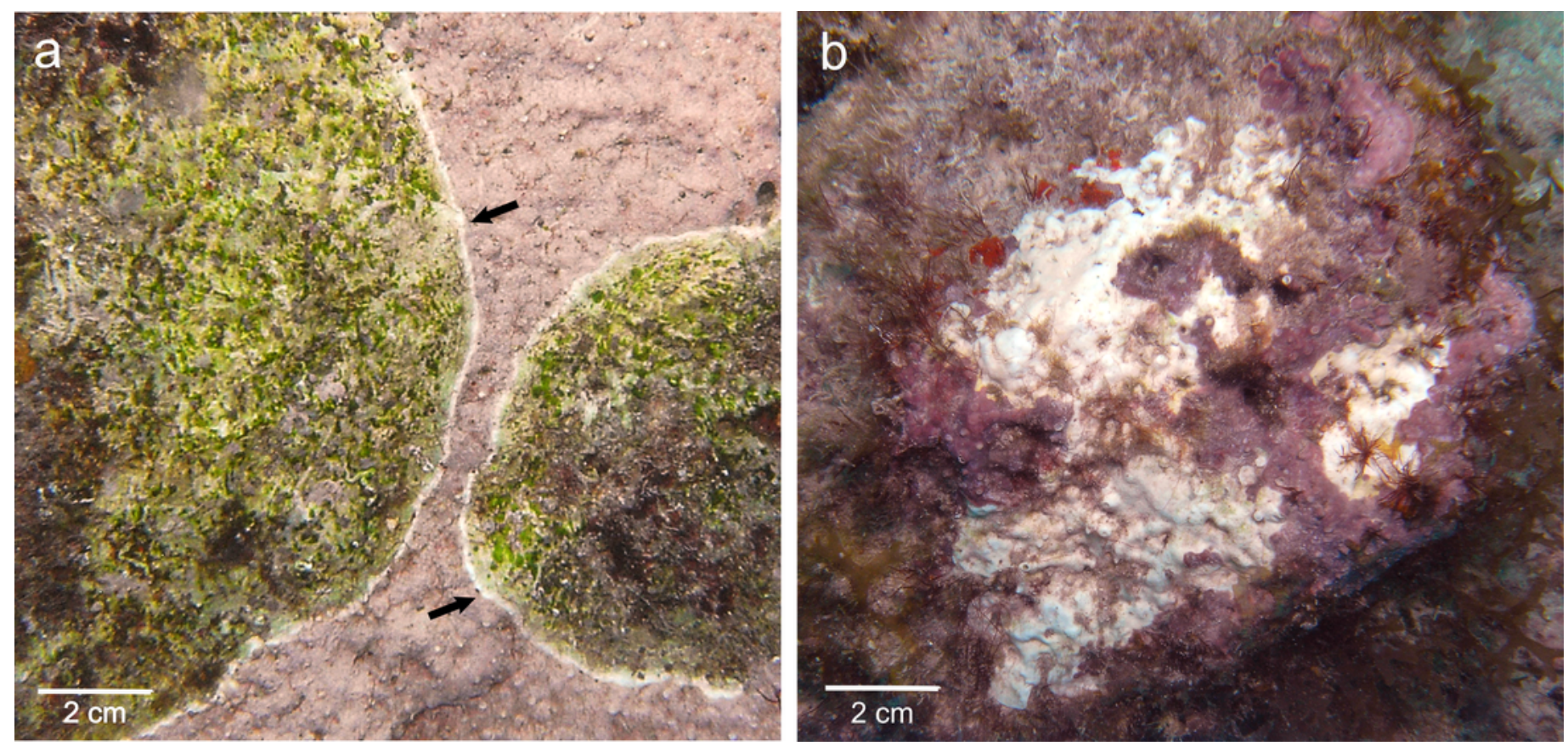


\section{2}

Transversal histological sections of the CCA, Paragoniolithon solubile affected by CWBS stained in Sharman's (1943) stain.

(a) overview with locations of the healthy, transition and dead areas enlarged in (b), (c) and (d). Note the progressive loss of staining from healthy tissue (HT) to dead tissue(DT). B, Boundary. Ep, epithallial cells. Cw, cell wall (silver stain). P, protoplasm (orange to dark stain).

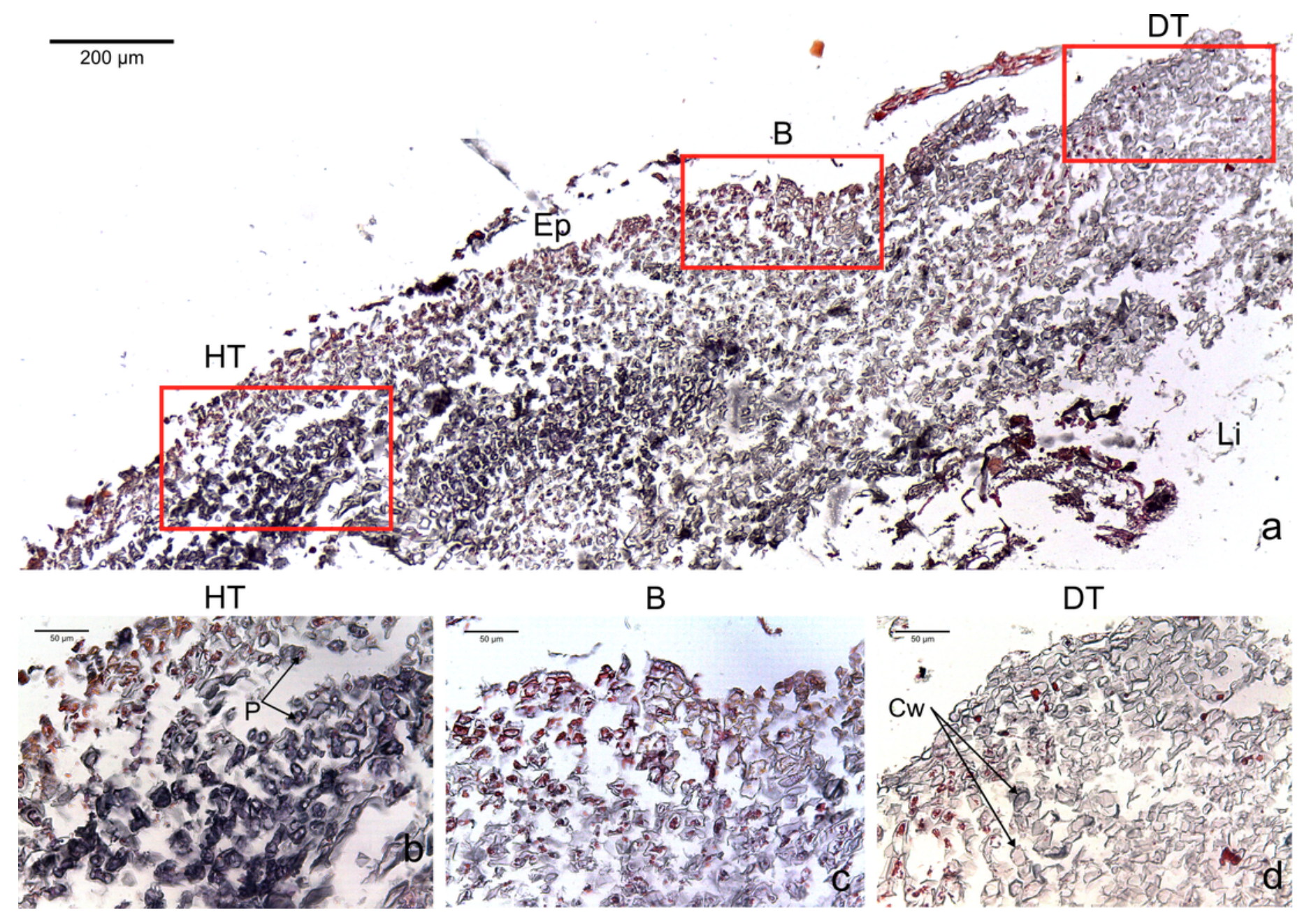




\section{3}

Transversal histological sections of the CCA, Hydrolithon boergesenii affected by CWPD stained in Sharman's (1943) stain.

(a) overview with locations of the healthy (HT) and diseased areas (DT) enlarged in (b) and (d). (C) shows the boundary (B) between healthy and diseased areas. Note the absence of a transition area highlighted by sudden loss of staining. B, Boundary. Co, conceptacle. Ep, epithallial cells. Cw, cell wall (silver stain). P, protoplasm (orange to dark stain). 

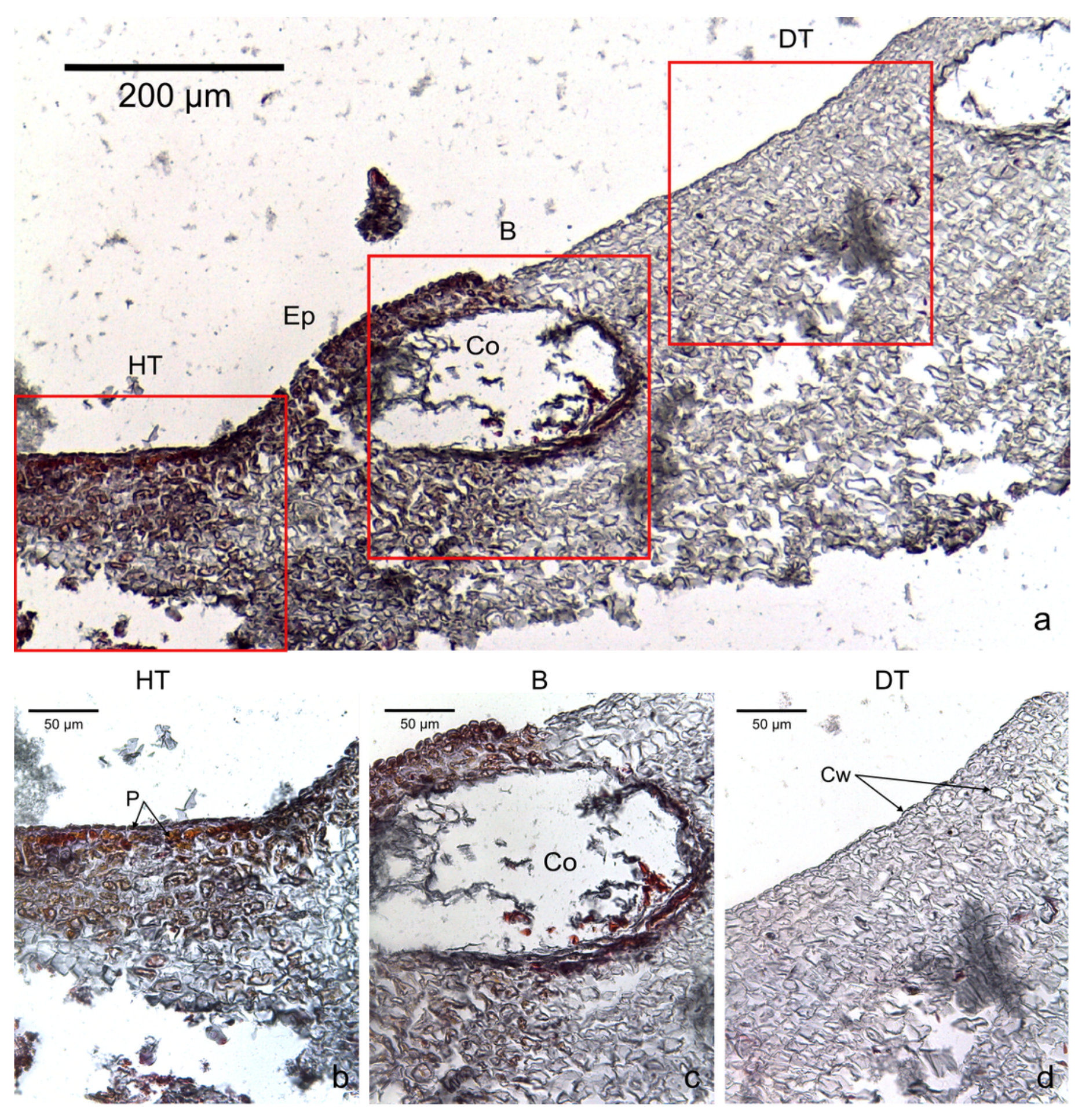
4

Regrowth of living crust.

Regrowth of living crust in (a) CWBS and (b) CWPD. Remnant healthy crust (red arrows) regrew upward and laterally over dead/dying crust. Insert in (a) displays enlargement of transition area with cells showing a condensed nucleus or protoplasmic content (black arrows). T, Transition. Ep, epithallial cells. 

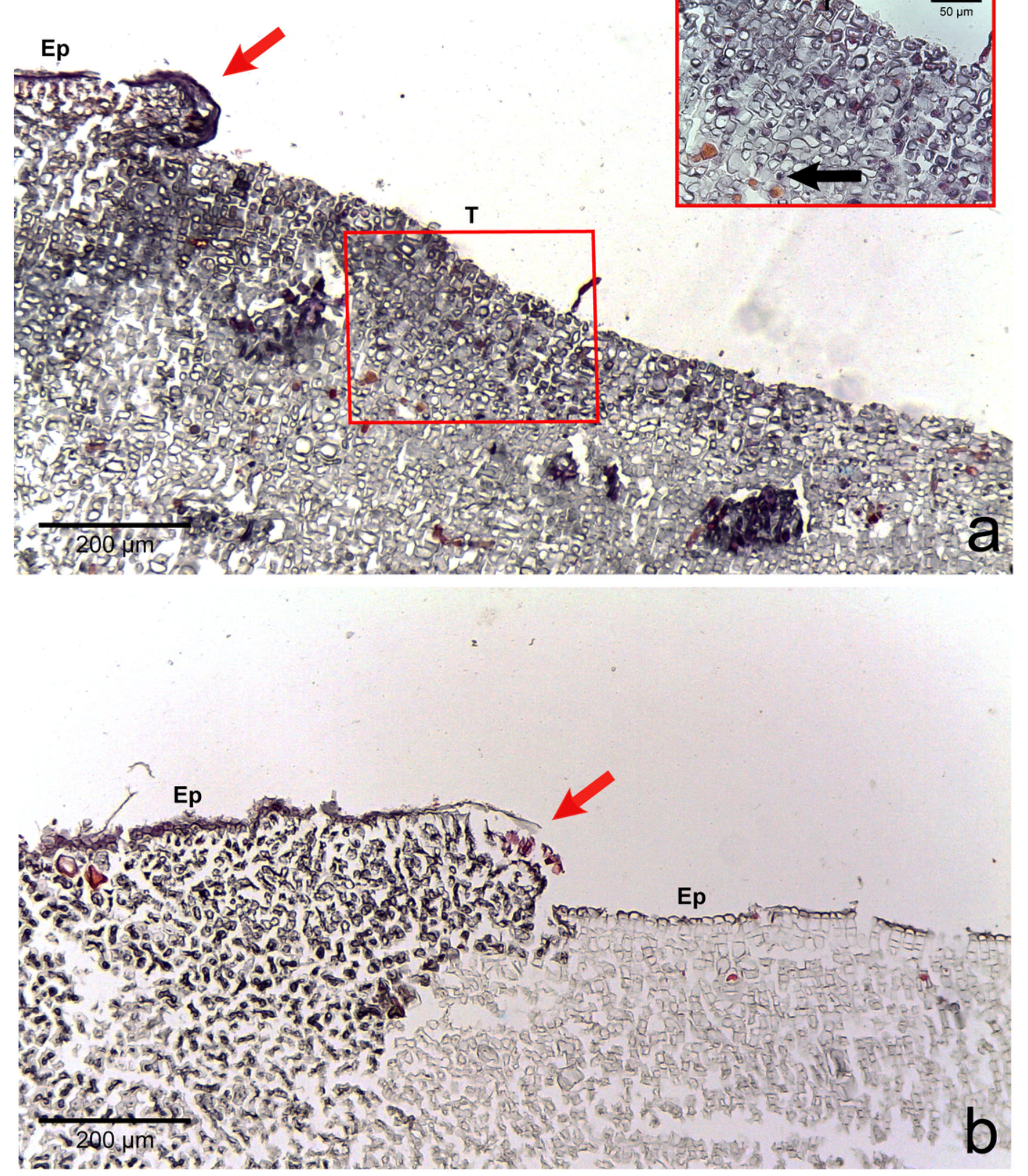


\section{5}

Photomicrographs of the most commonly encountered organisms in healthy and diseased CCA.

(a) boring sponge characterized by silicaceous spicules (red arrow) (b) Unidentified macroborer. Note the CCA cells lining up the burrow suggesting the growth of the algae around the invader (red arrow) and the acellular space around the organism (black arrow). (c) Unidentified macroborer, possibly a juvenile bivalve. (d) Cyanobacterial trichomes (red arrows). (e) Helminth. Cu, cuticule. L, lumen. 

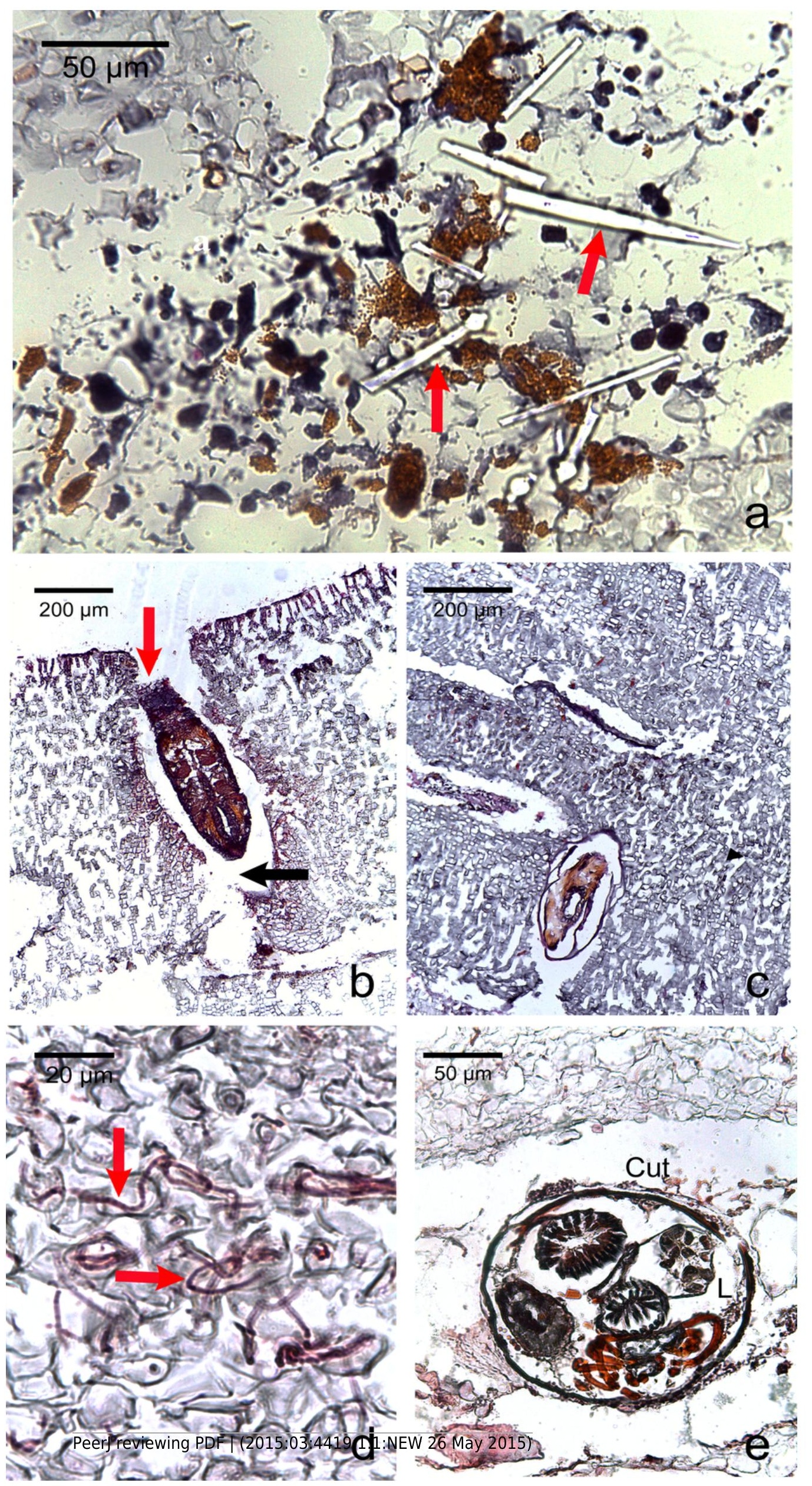


\section{Table 1 (on next page)}

Number of healthy and diseased fragments collected from each species 


\begin{tabular}{lrrrr}
\hline & Healthy & CWBS & CWPD & Total \\
\hline Hydrolithon boergenesii & 3 & 1 & 5 & 9 \\
Neogoniolithon mamillare & 2 & 4 & 3 & 9 \\
Paragoniolithon solubile & 1 & 3 & 0 & 4 \\
Paragoniolithon accretum & 1 & 0 & 0 & 1 \\
Total & 7 & 8 & 8 & 23 \\
\hline
\end{tabular}




\section{Table 2 (on next page)}

Number of samples with boring organisms

Number of samples with boring organisms partitioned by health status of CCA fragments (i.e. healthy, CWBS vs. CWPD), health of tissue within fragment (i.e. healthy vs. diseased) and vertical layer within fragment (i.e. CCA crust vs. limestone). HT, healthy tissue. DT, diseased tissue. $C$, crust. $L$, limestone. $T$, total fragment. Note that the numbers can add up more than for the total fragments since the same fragment may have borers in different sections of the sample. 


\begin{tabular}{|c|c|c|c|c|c|c|c|c|c|c|c|c|c|}
\hline \multirow{3}{*}{$\begin{array}{l}\text { Health of fragment } \\
\text { Health of tissue } \\
\text { Vertical layer }\end{array}$} & \multicolumn{3}{|c|}{ Healthy } & \multicolumn{5}{|c|}{ CWBS } & \multicolumn{5}{|c|}{ CWPD } \\
\hline & \multicolumn{2}{|c|}{ HT } & \multirow[b]{2}{*}{$\mathrm{T}$} & \multicolumn{2}{|c|}{ HT } & \multicolumn{2}{|c|}{ DT } & \multirow[b]{2}{*}{$\mathrm{T}$} & \multicolumn{2}{|c|}{ HT } & \multicolumn{2}{|c|}{ DT } & \multirow[b]{2}{*}{$\mathrm{T}$} \\
\hline & $\mathrm{C}$ & $\mathrm{L}$ & & $\mathrm{C}$ & $\mathrm{L}$ & $\mathrm{C}$ & $\mathrm{L}$ & & $\mathrm{C}$ & $\mathrm{L}$ & $\mathrm{C}$ & $\mathrm{L}$ & \\
\hline Number of samples & & & 7 & & & & & 8 & & & & & 8 \\
\hline Samples with borers & 1 & 3 & 4 & 2 & 4 & 2 & 6 & 8 & & 1 & & 5 & 5 \\
\hline Samples with sponges & & 3 & 3 & 2 & 2 & 3 & 4 & 5 & & 1 & & 5 & 5 \\
\hline Samples with helminths & & & & & & & 1 & 1 & & & & & \\
\hline Samples with other macroborers & 1 & 1 & 2 & 2 & 3 & 1 & 3 & 4 & & & & & \\
\hline Samples with cyanobacteria & & & & & 2 & & 2 & 3 & & & & 1 & 1 \\
\hline
\end{tabular}

